\title{
L-STAR PULSED COAL COMBUSTOR FOR RESIDENTIAL SPACE HEATING
}

\author{
QUARTERLY PROGRESS REPORT \\ FOR THE PERIOD \\ NOVEMBER 1988 - JANUARY 1989
}

prepared for

U.S. DEPARTMENT OF ENERGY

WORK PERFORMED UNDER

CONTRACT DE-AC22-87PC79652

prepared by

AVCO RESEARCH LABORATORY, INC.

a subsidiary of Textron Inc.

2385 Revere Beach Parkway

Everett, MA 02149 


\section{DISCLAIMER}

This report was prepared as an account of work sponsored by an agency of the United States Government. Neither the United States Government nor any agency Thereof, nor any of their employees, makes any warranty, express or implied, or assumes any legal liability or responsibility for the accuracy, completeness, or usefulness of any information, apparatus, product, or process disclosed, or represents that its use would not infringe privately owned rights. Reference herein to any specific commercial product, process, or service by trade name, trademark, manufacturer, or otherwise does not necessarily constitute or imply its endorsement, recommendation, or favoring by the United States Government or any agency thereof. The views and opinions of authors expressed herein do not necessarily state or reflect those of the United States Government or any agency thereof. 


\section{DISCLAIMER}

Portions of this document may be illegible in electronic image products. Images are produced from the best available original document. 
LE90 00G170

L-STAR PULSEO COAL COMBUSTOR FOR RESIOENTIAL SPACE HEATING

QUARTERLY PROGRESS REPORT
FOR THE PERIOD
NOVEMBER 1988-JANUARY 1989

MARCH 1989

prepared for

U.S. DEPARTMENT OF ENERGY

WORK PERFORMED UNOER CONTRACT OE-AC22-87PC79652

prepared by

AVCO RESEARCH LABORATORY, INC.

a Subsidiary of Textron Inc.

2385 Revere Beach Parkway

Everett, MA 02149

\section{DISCLAIMER}

This report was prepared as an account of work sponsored by an agency of the United States Government. Neither the United States Goverument nor any agency thereof, nor any of their employees, makes any warranty, express or implied, or assumes any legal liability or responsibility for the accuracy, completeness, or usefulness of any information, apparatus, product, or process disclosed, or represents that its usc would not infringe privately owned rights. Reference herein to any specific commercial product, process, or service by trade name, trademark, manufacturer, or otherwise does not necessarily constitute or imply its endorsement, recommendation, or favoring by the United States Government or any agency thereof. The views and opinions of authors expressed herein do not necessarily state or reflect those of the United States Government or any agency thereof. 
TABLE OF CONTENTS

Section

Page

List of Illustrations

i i i

1.0 CONTRACT OBJECTIVE

1

2.0 SUMMARY OF PROGRESS

2

3.0 TECHNICAL STATUS

3

4.0 FUTURE PLANS

14 


\section{LIST OF ILLUSTRATIONS}

Figure

Page

$1 \quad$ Induced Recharging Combustor Configuration 4

2 Bottom to Top Forced Airflow Configuration 5

3 . Flame Holder Plate 10

4 Bottom to Top Forced Airflow Configuration with Flame 12 Holder

5 Correlation between Coal Carbon Conversion and Average $\mathrm{CH}_{4}$ Concentration in the Outlet Gases 


\subsection{CONTRACT OBJECTIVE}

The objective of this contract is the design, fabrication, and testing of a residential size pulsed combustion system based on the L-star concept. Phase I of the program consists of the bulk of the development and optimization. of the combustor, while Phase II is to be centered around complete system development. The scope of work in Phase I is as follows:

Task 1 - Experimental System Design

Task 2 - Reactor Fabrication/Facility Modification

Task 3 - Combustion Characterization 


\subsection{SUMMARY OF PROGRESS}

During this quarter, substantial improvement in the coal carbon conversion was achieved. Specifically, for a scaled-down version of the residential combustor, coal carbon conversions exceeding 97 percent were realized, when utilizing methane as carrier gas for the coal. (Although technically not within the November-January period, it should be mentioned here that in March a few design changes have resulted in $>99$ percent coal carbon conversion, with no electric spark and complete elimination of methane during coal combustion and in a residential scale unit.)

Design changes made during this quarter include insulation of the combustor, introduction of a flame holder, combustion air preheat and presence of an obstructing plate at the combustor exhaust port. Only the first two changes contributed towards substantial improvement in coal conversion. In addition, monitoring of $\mathrm{CH}_{4}$ concentration in the exhaust gases gave a real time indication of the combustor performance.

Finally, the results of experiments performed in this quarter contributed to design changes that have led to a combustor that has achieved the program goal of $>99$ percent conversion of coal carbon. These changes and the results will be described in the final report. 


\subsection{TECHNICAL STATUS}

During this quarter, several avenues were investigated to optimize coal carbon conversion. Two basic combustor configurations were tested, the second resulting in a $>97$ percent coal carbon conversion.

First an induced recharging configuration was set up as shown in Figure 1. In this configuration, combustion of the fuel/air mixture drives gas out of the combustor, with the majority of the flow going toward the exhaust because of the combined effects of the exhaust fan and the diode flow resistance. The water-cooled combustor walls induce densification of the combustion gases, drawing in fresh air to repeat the cycle again.

This was indeed the case, as several runs of a few minutes duration were carried out. However, the amount of fresh air drawn in was insufficient to operate at an acceptable heat release rate. Also, there was some unburned coal remaining in the combustor after each run.

It was therefore decided to modify the combustor such that it features forced airflow of sufficient quantity and hot combustor walls. As shown in Figure 2, this was accomplished by reconnecting the small blower used in the past and lining the inside of the combustor with a flexible ceramic fiber blanket approximately 2 inches thick, which considerably decreased the effective volume of the combustor. It should be noted that unlike all of the experiments performed on this program to date, in this case the air flow was from bottom to top. In this configuration, good retention and hot walls are achieved.

After fine tuning during several short runs, an extended duration test was conducted. To preheat the system, methane without coal was combusted for 37 minutes in a pulsed manner. Immediately afterwards, coal with methane as a 


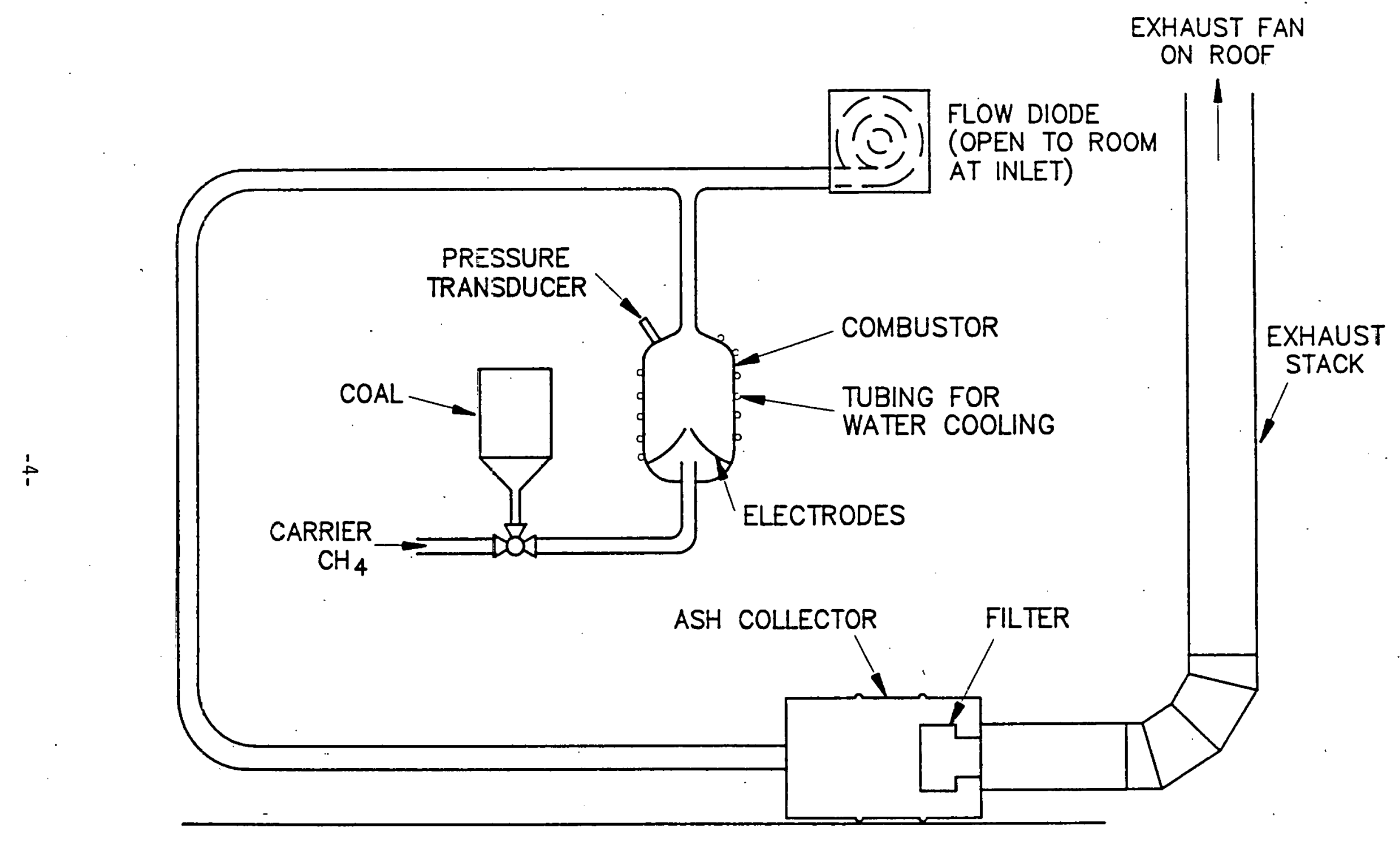

M9163

Figure 1: Induced Recharging Combustor Configuration 


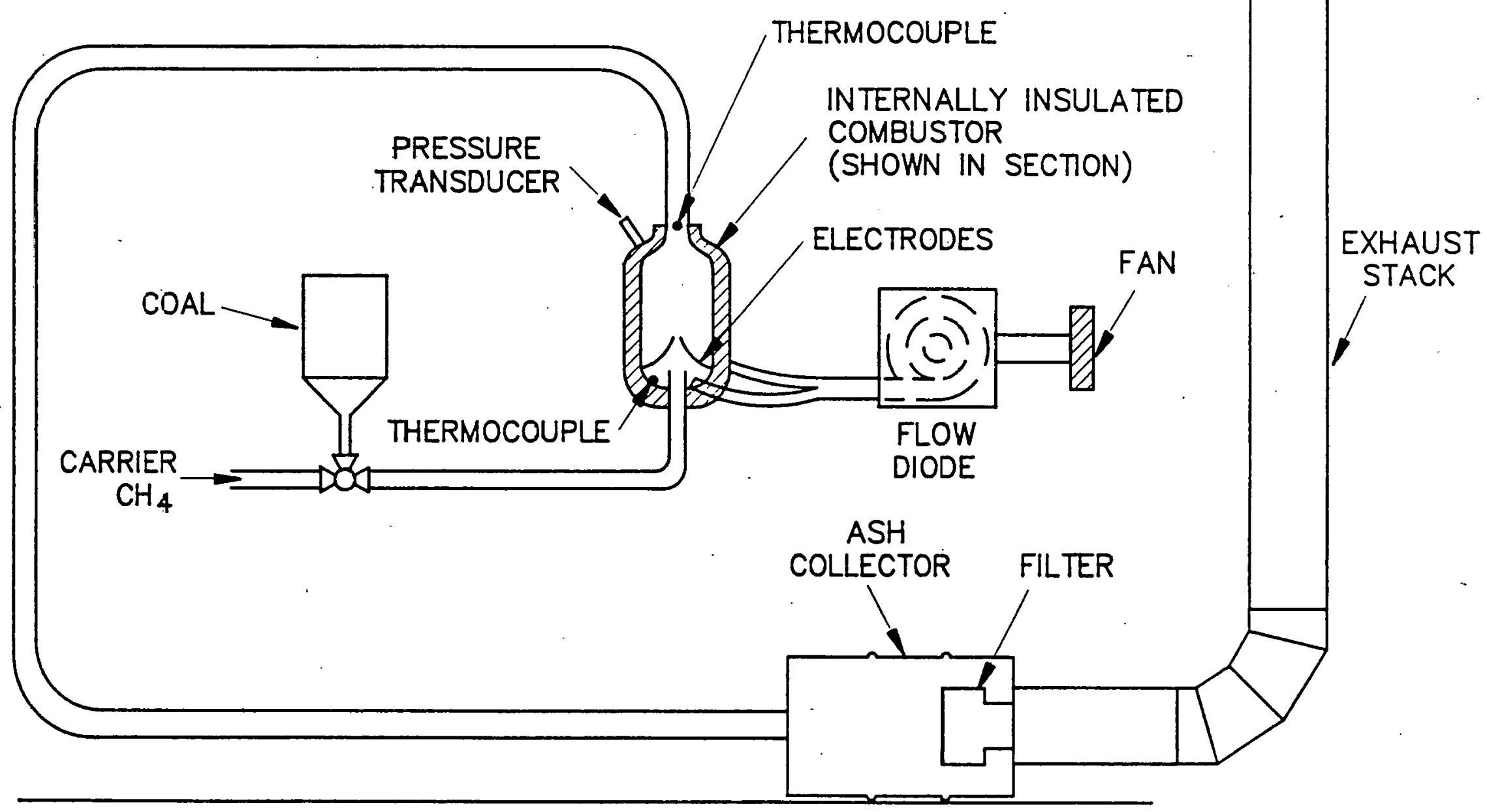

M9164-

Figure 2: Bottom to Top Forced Airflow Configuration 
carrier gas was combusted for 38 minutes. This run yielded 97.9 percent coal conversion. No unburned coal, or even char, was found in the combustor. A mere $2 \mathrm{~g}$ was recovered from the downstream filter assembly (analys is not performed) out of $96.5 \mathrm{~g}$ fed to the combustor. A summary of the variation with time of the combustion products and combustor temperature is presented in Table 1.

After this initial run, several runs were performed with this new configuration of up to three hours duration. Minor changes were made from run-to-run to optimize performance. Specifically, the effect of variations of the following parameters were studied: run duration, flow resistance, combustion air preheat, presence of the aerodynamic diode, and presence of an obstructing plate at the combustor exhaust port to retain solids. The results of these tests are presented in Table 2. Because chemical analysis of collected solids are not performed in all cases, two estimates of coal carbon conversion which should bracket the actual value are provided. The constant carbon method assumes that the collected coal is identical in composition to the input coal. The ash allowance method assumes that all the ash present in the input coal is recovered, and that any excess collected material is pure carbon. Because multiple variables are involved, neither method can be expected to always yield a higher value than the other.

While it is difficult to draw statistically significant conclusions from the data at this point, certain points are evident. Most obvious is the unexpectedly negative influence of preheating the combustion air. A comparison of the data from runs 4 and 5 shows that conversion was 6 percent lower when the combustion air was preheated under otherwise identical conditions. It is conceivable that the increased velocity of the heated, less dense air under essentially constant mass flow conditions results in more coal being carried away unburned. In any case, this approach has not been pursued further. 
TABLE 1

\begin{tabular}{|c|c|c|c|c|c|c|}
\hline Time & Temp Top & TempBottom & $8 \mathrm{O}_{2}$ & $\approx \mathrm{CO}_{2}$ & $\& \mathrm{CO}$ & $\& \mathrm{CH}_{4}$ \\
\hline & \multicolumn{6}{|c|}{ Methane Only for Warmup } \\
\hline $7 \mathrm{~min}$ & $1123^{\circ} \mathrm{F}$ & $143^{\circ} \mathrm{F}$ & 13.63 & 4.03 & - & .115 \\
\hline 12 & 1150 & 175 & 13.30 & 4.17 & - & .115 \\
\hline 17 & 1152 & 202 & 12.85 & 4.38 & - & .115 \\
\hline 22 & 1151 & 218 & 12.42 & 4.60 & - & .110 \\
\hline 27 & 1150 & 239 & 11.91 & 4.90 & - & .110 \\
\hline 32 & 1136 & 259 & 11.37 & 5.16 & - & .110 \\
\hline 37 & 116 & 271 & 11.22 & 5.27 & - & .100 \\
\hline
\end{tabular}

Methane and Beulah Zap

$\begin{array}{rrrrrrr}3 & 1005 & 348 & 7.65 & 8.59 & .01 & .170 \\ 8 & 1015 & 490 & 5.92 & 9.72 & .017 & .155 \\ 13 & 1020 & 570 & 5.49 & 9.99 & .018 & .135 \\ 18 & 1020 & 605 & 5.21 & 10.22 & .022 & .135 \\ 23 & 1030 & 630 & 5.07 & 10.26 & .026 & .135 \\ 28 & 1022 & 650 & 4.82 & 10.46 & .032 & .145 \\ 33 & 1025 & 650 & 4.62 & 10.70 & .022 & .105 \\ 38 & 1010 & 670 & 4.60 & 10.64 & .026 & .115\end{array}$


TABLE 2

Run Number

Duration (minutes)

Diode in Place

Heat Exchanger in Place

Preheated Air $\left(600^{\circ} \mathrm{F}\right)$

Obstructing Plate

Typical Exhaust Gas Composition

$\mathrm{CH}_{4}(\mathrm{ppm})$

$\mathrm{CO}$ (ppm)

$\mathrm{CO}_{2}$ (8)

$0_{2}(8)$

Temperature-Upper Thermocouple $\left({ }^{\circ} \mathrm{F}\right)$

Temperature-Lower Thermocouple $\left({ }^{\circ} \mathrm{F}\right)$

Coal Carbon Conversion ( 8 )

Constant Carbon Method

Ash Allowance Method

$\begin{array}{cc}1 & 2 \\ 180 & 30 \\ Y & Y \\ Y & Y \\ N & N \\ N & N\end{array}$

3
180
$Y$
$Y$
$N$
$N$

4
100
$N$
$N$
$Y$
$N$

$$
\underline{5}
$$

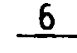

60

180

100

$N$

$N$

$\mathrm{N}$

$N$

Y

$N$

N

N

7

$$
Y
$$$$
\text { N }
$$$$
\text { N }
$$

$\begin{array}{rrrrcrc}620 & 3770 & 560 & 540 & 280 & 3680 & 410 \\ 1400 & 720 & - & - & - & - & - \\ 11.6 & 13.0 & 10.3 & 8.0 & 6.8 & 4.5 & 5.6 \\ 3.2 & 1.8 & 5.4 & 11.9 & 10.3 & .13 .8 & 11.9 \\ & & & & & & \\ 1140 & 1334 & 1190 & 1227 & 1260 & 1170 & 1130 \\ 800 & 746 & 650 & 612 & 420 & 178 & 260\end{array}$

$\begin{array}{lllllll}97.6 & 90.2 & 95.7 & 88.4 & 94.0 & 91.8 & 95.2 \\ 98.9 & 85.0 & 95.3 & 81.9 & 92.2 & 88.1 & 94.4\end{array}$

All tests were performed at a pLilse repetition rate of $.875 \mathrm{HZ}$ and a heat release rate of $6700 \mathrm{BTU} / \mathrm{HR}$. 
The remaining runs all exhibited worst case conversion in excess of 85 percent, with a maximum of 97.6-98.9 percent being achieved for run \#1 featuring the diode, the increased flow resistance of the heat exchanger, no preheated air, and no exhaust obstruction plate for a run duration of three hours.

Other conclusions can be drawn from the available data. In all cases, residual solids are collected only from the ash collector; the combustor itself is always free of coal. Consequently, one must assume that the solids collected for each run are being carried out of the combustor at least partially unburned and that the problem is primarily one of residence time. Attempts to reduce the air flow enough to preclude this problem resulted only in a too-rich condition (carbon monoxide present). A 1 inch diameter obstruction placed in the 2 inch diameter exhaust orifice failed to retain the particles. Run duration does not appear to be a critical factor.

Subsequent experiments were conducted to fine tune both the combustor geometry and the test procedure in order to achieve as high as possible coal carbon conversion. During the tests, the following parameters were kept constant.

1) The combustion air was not preheated.

2) The aerodynamic diode was always in place.

3) The heat exchanger was removed.

4) An obstruction plate was kept in place since its presence did not affect the coal conversion levels.

Two changes were, however, made. First, a flameholder (see Figure 3) was designed and installed, in order to introduce recirculatory zones in the combustor and hence increase residence time at the coal particles. The 


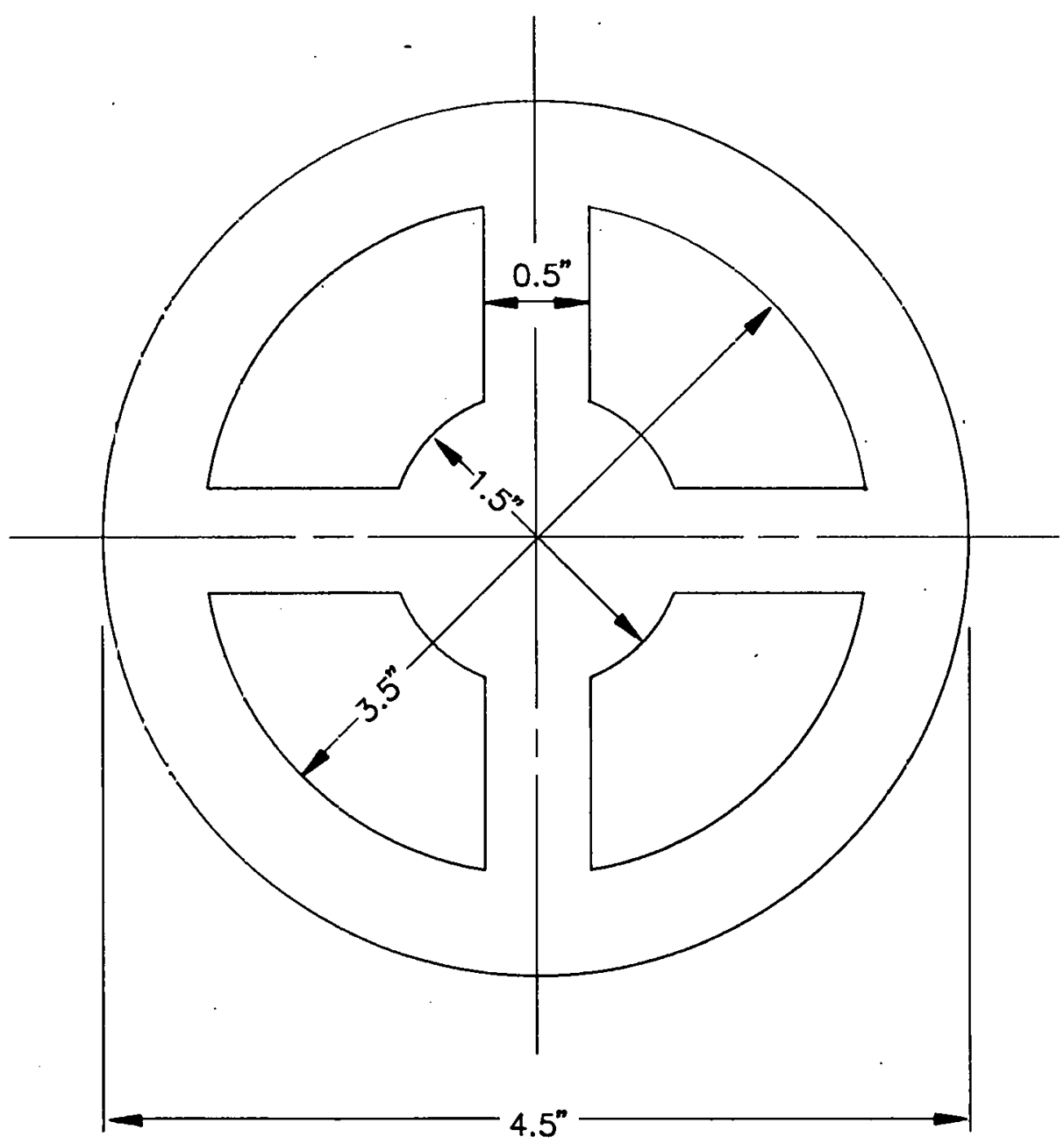

M9760

Figure 3: Flame Holder Plate 
flameholder was placed in the primary combustion zone approximately 3 " over the electrodes. Figure 4 shows the combustor arrangement used for this series of tests (notice the flameholder location). A relatively good coal carbon conversion of 96.7 percent was observed as a result of this change. Second, a thermo-anemometer was installed in the air flow line to measure the air mass flow at the exit of the fan.

This was a considerable improvement over the previous procedure where the air mass flow was not recorded during the test, but rather before and after it, giving only continuous flow measurements. In addition, this gave the ability to introduce the air mass flow as a new well controlled parameter. A bleed-off valve in the line gave good control of the air flow between 2.2 and $3.5 \mathrm{ft}^{3} / \mathrm{min}$ (typical air flow approximately $2.9 \mathrm{ft}^{3} / \mathrm{min}$ ).

An important experimental observation was also made from these runs. The time averaged (over the test time $1-3 \mathrm{hrs}$ ) $\mathrm{CH}_{4}$ volumetric concentration at the combustor outlet, as measured by the gas analyzer, was found to correlate with the coal carbon conversion. This can be seen in Figure 5 where the results of a series of tests under various conditions are plotted. According to this figure, the coal carbon conversion increases as the volumetric concentration of $\mathrm{CH}_{4}$ in the outlet gases decreases. The $\mathrm{CH}_{4}$ concentration in the outlet gases can be kept low during the tests by adjusting the air mass flow. Therefore the volumetric concentration of $\mathrm{CH}_{4}$ can be used as a "real-time." on-line indicator of coal carbon conversion. 


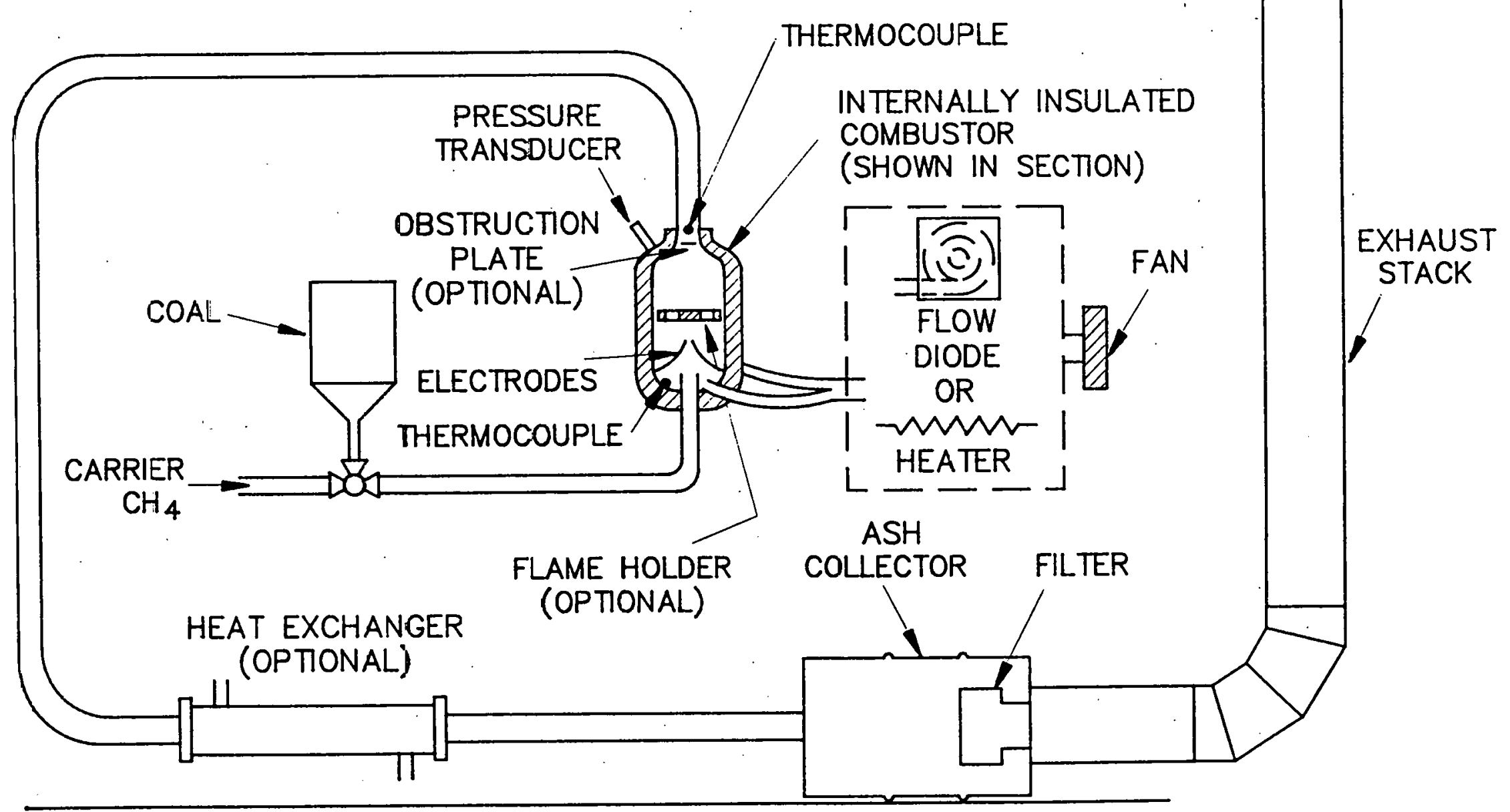

M9214-1

Figure 4: Bottom to Top Forced Airflow Configuration with Flame Holder 


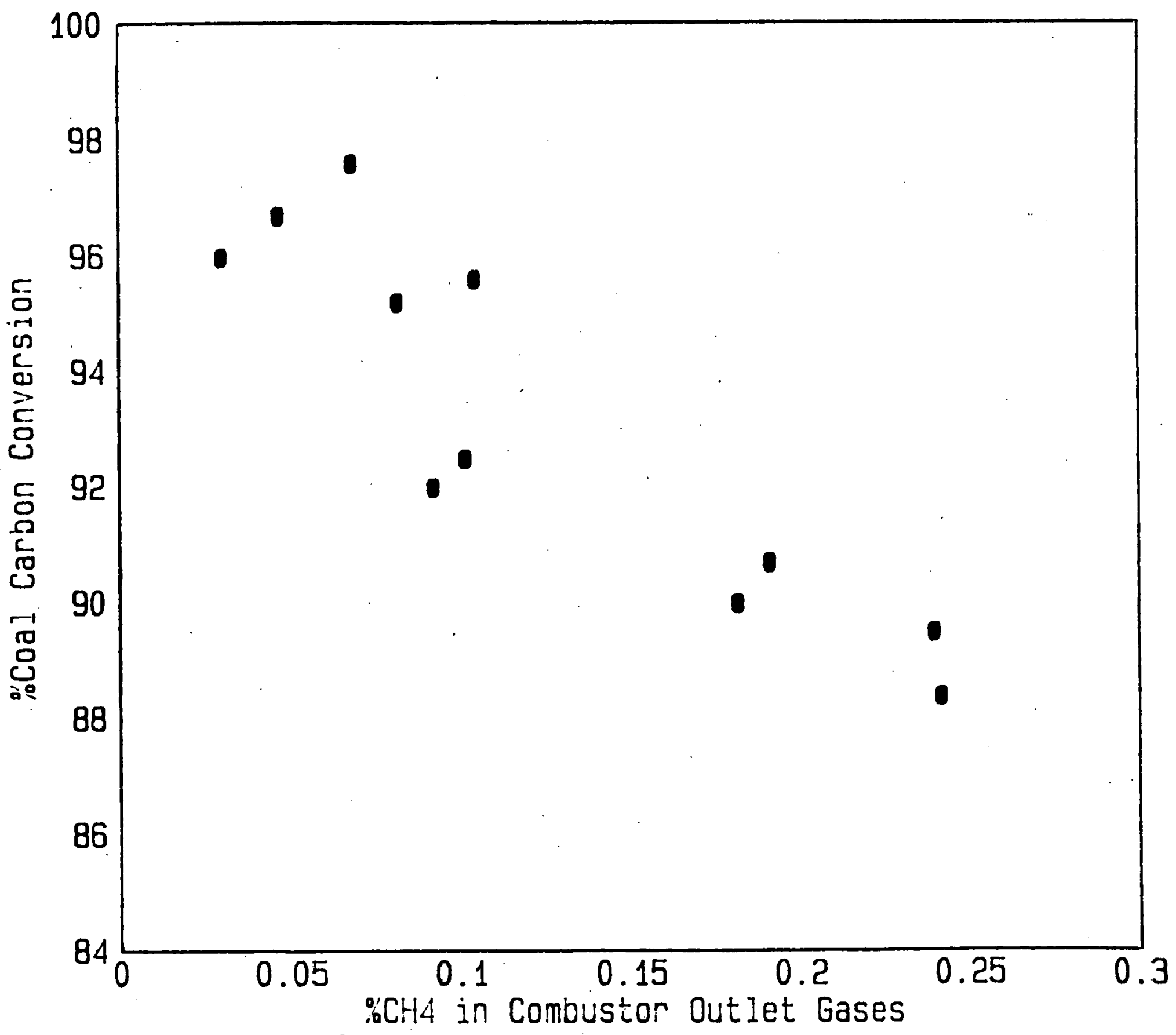

Figure 5: Correlation between Coal Carbon.Conversion and Average $\mathrm{CH}_{4}$ Concentration in the Outlet Gases 


\subsection{FUTURE PLANS}

Since $>97$ percent coal carbon conversion was achieved in this quarter with a scaled-down version of the combustor, it is planned to first scale the combustor back to residential scale. Initial effort would be directed to obtaining the same high conversions in the residential scale combustor. with methane assist. The combustor will be fitted to allow introduction of secondary air downstream of the flame holder, so as to provide better mixing of partially combusted products with fresh air.

Once high conversions are achieved, the next goal is to reduce the amount of methane assist with the ultimate aim of complete elimination of methane. Finally, the performance combustor will be tested when running without an electric spark. Tests up to three hours duration will be performed. (In March 1989 all the above goals were achieved.) 